\title{
THE EFFECT OF Kluyveromyces lactis STARTER CONCENTRATION AND FERMENTATION TIME TO THE PHYSICOCHEMICAL AND FUNCTIONAL PROPERTIES OF EGG WHITE POWDER
}

\author{
Andry Pratama*, Wendry Setiadi Putranto, Kusmajadi Suradi, Robiatul Adawiyah, Risanawati, Chintia Ninda \\ Departement of Animal Products Technology, Faculty of Animal Husbandry, Padjadjaran University, \\ Sumedang 45363, Indonesia \\ *Corresponding author: andry.pratama@unpad.ac.id
}

Accepted 16 April 2019; Revised 10 September 2019

Published 17 October 2019

\begin{abstract}
The process of making egg white powder would determine the qualities of the product. One way to maintain the qualities of the egg white powder could be done through egg white fermentation prior to drying. This research aims to understand the effect of Kluyveromyces lactis fermentation on egg white at different starter concentrations and fermentation time to the physicochemical and functional properties of the egg white powder. The research is conducted in a completely randomized design experiment with nested treatment. The $K$. lactis starter concentrations were divided into 3 groups $(\mathrm{P} 1=0.2 \%$; $\mathrm{P} 2=0.4 \%$; and $\mathrm{P} 3=0.6 \%)$, and the fermentation times were divided into two groups $(\mathrm{W} 1=12 \mathrm{~h}$; and $\mathrm{W} 2=24 \mathrm{~h}$ ), with all treatments were repeated four times and nested on the starter concentration. The results showed that concentration $K$. lactis starter concentration and fermentation time gave no significant effect to the physicochemical and functional $(\mathrm{pH}$, yield, solubility, water, ash, and carbohydrate content, and colours $\left.\left(\mathrm{L}^{*}, \mathrm{a}^{*}, \mathrm{~b}^{*}\right)\right)$ properties, but increase the protein content of the egg white powder. The research concludes that egg white fermentation with $0.6 \%$ Kluyveromyces lactis concentration for $24 \mathrm{~h}$ gave the best physicochemical and functional properties of the egg white powder.
\end{abstract}

Keywords: Kluyveromyces lactis; physicochemical properties; functional properties; egg white powder 


\section{INTRODUCTION}

Chicken egg is one of the popular and preferred animal-based food. It is regarding that the chicken egg is cheap and widely available while also rich in nutrients (Lestari, 2009). Moreover, the egg white could be used in various food products, such us for bakeries or meat products, as it has foaming and other properties which would improve the texture of the food products. However, even though the egg white has high protein content (around 80\%), the egg white has short self-life which would become problems for big industries (Yuwanta, 2010). The processing of egg white into powder is one of the efforts to prolong its shelf life without decreasing its nutritional content and volume, thus would be more efficient and versatile to be used for various products.

The processing of egg white powder could be done through drying, however, the process would initiate Maillard reaction. The interaction between glucose with proteins in the egg white would decrease the produced egg white powder qualities, such as causing off-flavor, $\mathrm{pH}$ changes and brownish color (Lechevalier et al., 2007). The sugar fraction in the chicken egg white is around $0.4 \%$ to $0.9 \%$ (Yuwanta, 2010), while the standard for reduced sugar in the egg white powder is no more than $0.1 \%$. This showed the high possibilities of Maillard reacted to occur during egg white powder processing. In order to prevent the reaction, fermentation prior to egg white processing could be done which aimed to reduce the glucose content (Buckle et al., 2007). The longer fermentation would reduce more carbohydrate in the egg white, however, if the fermentation is done for to long, it would reduce the foaming and solubilities of the egg white due to protein degradation (Nahariah et al., 2018). One of the yeasts which have the ability to metabolize glucose in food products through fermentation is Kluyveromyces lactis. The yeast is categorized in phylum Ascomycotina, family Saccharomycetaceae, and genus Kluyveromyces.

Kluyveromyces lactis showed the ability to metabolize lactose, glucose, galactose, and produce $\beta$-galactosidase enzyme, which would reduce lactose in dairy milk (Roostita et al., 2014). Kluyveromyces lactis would have optimal growth in the $\mathrm{pH} 4.6-6.5$ medium at $25^{\circ} \mathrm{C}$. The glucose and galactose fermentation of the yeast is done through aerobic glycolysis, which produced pyruvic acid and followed with Acetyl-CoA. The Acetyl-CoA would then enter Krebs cycle and produced $\mathrm{CO}$, $\mathrm{H}_{2} \mathrm{O}$, and energy in the form of ATP (Yurliasni, 2009). This research is then conducted to understand the effect of different Kluyveromyces lactis starter concentration and fermentation time to the physicochemical and functional properties of egg white powder.

\section{MATERIALS AND METHODS}

\section{Materials}

The main materials in this research are $1500 \mathrm{~mL}$ egg whites from Lohman brown chicken which has been stored for a day in Layer Jaya Farm. The other materials used in this research were Kluyveromyces lactis isolates from Sekolah Ilmu dan Teknologi Hayati Institut Teknologi Bandung, 5\% citric acid, Malt Extract Broth (MEB), plastic wrap and clip, aluminum foil, and aquadest.

\footnotetext{
*Corresponding author:

Andry Pratama

Email: andry.pratama@unpad.ac.id

Department of Animal Product Technology, Faculty of Animal Husbandry, Padjadjaran University, Sumedang 45363, Indonesia
}

How to cite:

Pratama, A., Putranto, W. S., Suradi, K., Adawiyah, R., Risanawati., Ninda, C. (2019). The Effect of Kluyveromyces Lactis Starter Concentration and Fermentation Time to the Physicochemical and Functional Properties of Egg White Powder. Jurnal Ilmu dan Teknologi Hasil Ternak, 14 (2), 117-125 


\section{Methods}

\section{Starter solution}

Two to three streaks of $K$. lactis isolate were inoculated into $5 \mathrm{~mL}$ of MEB media and then incubated at $25^{\circ} \mathrm{C}$ for $24 \mathrm{~h}$ (culture 1). Furthermore, as much as $0.1 \mathrm{~mL}(0.1 \%)$ of culture 1 were taken for reinoculation in $100 \mathrm{~mL}$ MEB media at $25^{\circ} \mathrm{C}$ for $48 \mathrm{~h}$. The $K$. lactis isolate solution was then for the research.

\section{Egg White Powder Preparation (Modified from Nusa et al., 2017)}

The egg white powders were made by firstly separate the egg white from other egg parts, and then added with $5 \%$ citric acid until reached $\mathrm{pH}$ 6.5. The egg white is then pasteurized by using a water bath (Julabo TW20) at $62^{\circ} \mathrm{C}$ for $3 \mathrm{~min}$, then fermented for 12 and $24 \mathrm{~h}$ at $25^{\circ} \mathrm{C}$ in the incubator (Memmert IF55).
The sample for fermentation were divided according to the $K$. lactis starter concentrations, which were $0.2 \%$ (P1); $0.4 \%$ $(\mathrm{P} 2)$; and $0.6 \%(\mathrm{P} 3)(\mathrm{v} / \mathrm{v})$. The drying was done by using pan drying at $45^{\circ} \mathrm{C}$ for $22 \mathrm{~h}$ in the blast air oven (Yenaco YNC 30L). The dried egg whites were then turned into powder by using blender (Philips HR2157) followed by 80 mesh filtration.

\section{pH}

Ten grams of egg white powders were weighed and diluted into $100 \mathrm{~mL}$ aquadest in a beaker glass, and then stirred until homogenous. The $\mathrm{pH}$ of the sample was then measured by using a $\mathrm{pH}$ meter (Hanna $\mathrm{HI}$ 2210-02).

\section{Yields (AOAC, 2006)}

The egg white powder yields were measured by the following formula:

Yields $(\%)=\frac{\text { Total weight of the produced egg white powder }(\text { gram })}{\text { Total weight of the egg white }(\text { gram })} \times 100 \%$

Solubility (Modified from AOAC, 2006)

One gram of egg white powder was diluted into $100 \mathrm{~mL}$ aquadest and then filtered by using filter paper with the help of vacuum pump to precipitate the filtration process.
The filter paper along with the residues was then dried by using blast air oven (Yenaco YNC 30L) at $105^{\circ} \mathrm{C}$ for $3 \mathrm{~h}$. The filter paper was then weighed before and after cooled down in desiccator for $15 \mathrm{~min}$.

Solubility $=1-\frac{\text { (Total weight of filter paper and residues-filter paperweight) }}{\frac{(100-\% \text { water })}{100} \times \text { Sample weight }} \times 100 \%$

Functional Properties (Mulyani, 2012)

The results of rehydration were mixed again with Philips mixer at 680-700 rpm for 5 min.
The produced foam was tidied by using a spatula and then measured for its volume. The sample was then kept for an hour and then measured for foam seepage.

$$
\begin{gathered}
\text { Foaming }=\frac{\text { Foam volume }}{\text { Egg white volume }} \times 100 \% \\
\text { Foam stability }=100 \%-\left(\frac{\text { foam seepage }}{\text { foam volume }} \times 100 \%\right)
\end{gathered}
$$

Water content (AOAC, 2006)

Two grams of egg white powder was weighed and placed into an aluminum dish.
The sample was then dried in blast air oven (Yenaco YNC 30L) at $105-110^{\circ} \mathrm{C}$ for $3 \mathrm{~h}$. The sample was then cooled down in 
desiccator for 15 min before weighed again until reached constant weight. The water content of egg white powder was measured by following formula:

$$
\text { Water }(\%)=\frac{\text { Initial weight-final weight }}{\text { Initial weight }} \times 100 \%
$$

\section{Ash (AOAC, 2006)}

Five grams of egg white powder was burnt in tenure until ash was produced and reached constant weight. The burning was done in two steps, with the initial burning process was done at $400^{\circ} \mathrm{C}$ and the second burning process was at $500^{\circ} \mathrm{C}$, for $2 \mathrm{~h}$ both. The sample was then cooled down in desiccator before weighed and measured by following formula:

$$
\text { Ash } \%=\frac{\text { Ash weight }(\text { gram })}{\text { Sample weight }(\text { gram })} \times 100 \%
$$

\section{Protein (AOAC, 2006)}

The protein content was measured with Kjeldahl method, which was consisted of destruction, distillation and titration steps.

\section{Carbohydrate (AOAC, 2006)}

The carbohydrate content in egg white powder was measured with the Anthrone method. Two grams of sample was diluted in $250 \mathrm{~mL}$ aquadest, and then further diluted until eighth dilution was obtained. The standard sugar solution was then pipetted into reaction tube at $0 ; 0.2 ; 0.4 ; 0.6 ; 0.8$; and $1 \mathrm{~mL}$ for blank and sample solution, followed by aquadest addition until all solution had $1 \mathrm{~mL}$ volume. Five $\mathrm{mL}$ of Anthrone solution was then added on each tube, and heated for $12 \mathrm{~min}$. The sample was then observed for its carbohydrate content by using spectrophotometer (CARY 50 UV) at $630 \mathrm{~nm}$.

\section{Data analysis}

The research was conducted in a completely randomized design with nested treatments. The observed treatments were $K$. lactis starter concentrations $(0.2 ; 0.4$; and $0.6 \%)$ and fermentation time (12 and $24 \mathrm{~h}$ ) which nested in the concentration treatment. Each treatment was replicated four times.

\section{RESULTS AND DISCUSSIONS}

\section{The effect of $K$. lactis starter concentration and fermentation time on pH}

It can be seen from Table 1 that the average egg white powder $\mathrm{pH}$ in all treatments was relatively high (8.60-8.68). The finding is similar to the research by Roxana et al. (2015) which showed that the egg white powder $\mathrm{pH}$ is ranging from 8.00 to 8.20 .

The glucose in egg white is metabolized by $K$. lactis into $\mathrm{CO}_{2}$ and $\mathrm{H}_{2} \mathrm{O}$ through fermentation for the cell growth. The high $\mathrm{pH}$ in this study is allegedly caused by the long drying process, which would have resulted in $\mathrm{CO}_{2}$ and $\mathrm{H}_{2} \mathrm{O}$ evaporation from the egg white. The result is supported by Buckle et al. (2007) which stated that the loss of $\mathrm{CO}_{2}$ from the egg white would increase the $\mathrm{pH}$ value. Ariyanti and Hadiyanto (2013) added that the Kluyeromyces yeast would utilize sugar into ethanol and biomass.

Table 1. The effect of $K$. lactis fermentation to the physical properties of egg white powder

\begin{tabular}{lrrrrrr}
\hline \multirow{2}{*}{ Physical properties } & \multicolumn{2}{c}{ P1 } & \multicolumn{2}{c}{ P2 } & \multicolumn{2}{c}{ P3 } \\
\cline { 2 - 7 } & $12-\mathrm{h}$ & $24-\mathrm{h}$ & $12-\mathrm{h}$ & $24-\mathrm{h}$ & $12-\mathrm{h}$ & \multicolumn{1}{c}{ 24-h } \\
\hline $\mathrm{pH}$ & 8.65 & 8.60 & 8.62 & 8.62 & 8.68 & 8.68 \\
Yields (\%) & 11.05 & 11.31 & 11.09 & 9.21 & 9.80 & 9.95 \\
Solubility (\%) & 61.66 & 65.23 & 69.66 & 66.93 & 65.38 & 67.71 \\
\hline
\end{tabular}


The effect of $K$. lactis starter concentration and fermentation time on egg white powder yield

The $K$. lactis starter concentration combined with fermentation time did not give a significant effect to the egg white powder yield. The result was allegedly correlated with the carbohydrate content and moisture in the produced egg white powder. The result of carbohydrate and water content in the produced egg white powder is presented in Table 3.

The carbohydrate measurement showed that the carbohydrate content in egg white powder in this research were $0.19 \%$ (P1); $0.16 \%(\mathrm{P} 2)$; and $0.17 \%$ (P3). Thus, the results showed that the fermentation would decrease the carbohydrate of the egg white, as the normal carbohydrate content in egg white is around 0.40 to $0.90 \%$ (Bell and Weaver, 2002). Moreover, the water content would affect the yield as well. In this research, the water content of the egg white powder was $12.80 \%(\mathrm{P} 1) ; 12.51(\mathrm{P} 2)$; and $12.75 \%$ (P3). The water content of egg white powder in this research is higher than finding by Puspitasari (2006) which showed that the water content of egg white powder is ranging from $6.25 \%$ to $7.58 \%$. The water in egg white powder would stick the powder in the filter and grinder surface, thus reduced the obtained yields. The statistical analysis of water content in egg white powder did not show any significant differences, which is in line with the result of yield measurement as well. However, Ariyanti and Hadiyanto (2013) described that the obtained yields in fermentation products could be increased by the biomass production of bacteria. In their research on Kluyeveromyces yeast fermentation, the yields would be increased as much as $4.5 \mathrm{~g} / \mathrm{L}$ after $22 \mathrm{~h}$ of fermentation.

\section{The effect of $K$. lactis starter concentration and fermentation time on solubility}

The best egg white powder solubility was found in the $0.4 \% \mathrm{~K}$. lactis starter concentration, which showed $62.38 \%$ solubility. The solubility of the egg white powder is regarding that $K$. lactis is categorized as Ascomycotina, in Saccharomycetaeceae family, which is similar to $S$. cerevisiae in fermenting lactose, glucose, and galactose (Barnet and Pankhurst, 2000). The research showed that different starter concentration and time of fermentation did not give significant effect to the egg white powder solubility. The condition correlates with the insignificant effect of starter concentration and fermentation time to the $\mathrm{pH}$ as well. Luo and Shu (2012) showed that high $\mathrm{pH}$ would increase the hydroxyl group, which would increase the hydrophobic properties as well, thus reducing the solubility.

\section{The effect of $K$. lactis starter concentration and fermentation time on foaming}

The $K$. lactis starter concentration and time of fermentation did not give significant effect to the egg white powder foaming. Kluyveromyces lactis showed the ability to process glucose and protein in the egg white and produced protein metabolites which had the foaming properties. The egg white foaming in this research is higher compared to the finding by Triawati et al. (2013), which showed that the foaming of egg white after stored for a day is $445.55 \%$. In addition, research by Nusa et al. (2017) showed that the egg white foaming is around $356.74 \%$ after fermented with $0.4 \%$ tempeh yeast; and $345.70 \%$ after fermented for $24 \mathrm{~h}$. The high foaming abilities in this research could be resulted from the ovomucin breakdown due to the fermentation process. Ovomucin is a protein known to form foam. Pujimulyani et al. (2001) stated that the fermentation process could increase the foaming formation in duck egg by changing the tertiary ovomucin into secondary or primary form.

The tertiary ovomucin has a form of globules, which would have less foaming abilities compared to its secondary and primary form (Smith and Hull, 2014). Moreover, Rosa et al. (2013) stated that $K$. 
lactis fermentation would produce high protein metabolites, which resulted in high foaming formation as well.

\section{The effect of $K$. lactis starter concentration and fermentation time on foaming stability}

The result showed that 12-h fermentation had higher foam stability compared to the $24-\mathrm{h}$ fermentation. It is noting that longer fermentation would result in higher structural change in protein. Moreover, the egg white $\mathrm{pH}$ is also known to affect the egg white stability. The average $\mathrm{pH}$ of the egg white powder in this research is 8.6. The result is in accordance with Winarti and Trianini (2005) that showed the best egg white foaming would occur in the $\mathrm{pH}$ around 6.5-9.5. Kluyveromyces lactis showed the ability to metabolize egg white glucose and protein during fermentation, and produced protein metabolites, even though the result is not significantly different.

\section{The effect of $K$. lactis starter concentration and fermentation time on water content}

Kluyveromyces lactis showed the ability to metabolize compounds in egg white through the fermentation process and produced $\mathrm{H}_{2} \mathrm{O}$ metabolites. In this study, the produced water content was not significantly different, but higher than the standard by National Standardization Agency of Indonesia, which determined that the maximal water content in egg white is $8 \%$. The result is regarding that the fermentation would alter ovomucin structure in the egg white from tertiary into secondary structure, and produced water in the process.

The changes in protein structure during fermentation would result in more active groups which had stronger waterbinding potential the protein. It is supported by Yurliasni (2009) who stated that K. lactis would grow by utilizing glucose and galactose through aerobic glycolysis for metabolism. The process would then produce $\mathrm{CO}_{2}, \mathrm{H}_{2} \mathrm{O}$, and ATP as the final products.

\section{The effect of $K$. lactis starter concentration and fermentation time on ash content}

The TPC measurement showed that the produced $K$. lactis biomass tend to increase during fermentation, which resulted in $1.0 \times 10^{7} \mathrm{CFU} / \mathrm{mL}$ after 12 -h fermentation and $3.9 \times 10^{7} \mathrm{CFU} / \mathrm{mL}$ after 24-h fermentation. This condition is allegedly affecting the ash content in the produced egg white powder, thus higher $K$. lactis starter concentration would increase the ash content as well. Roosita et al. (2014) stated that mineral content of $S$. cerevisiae is $7-8 \%$. Kalium is one of essential mineral for yeast. Roosita et al. (2014) stated that potassium would be functioned as cofactor of various oxidative phosphorylation enzymes, protein synthesis, and carbohydrate metabolism.

Table 2. The effect of $K$. lactis fermentation to the functional properties of egg white powder

\begin{tabular}{lrrrrrr}
\hline \multirow{2}{*}{ Functional Properties } & \multicolumn{2}{c}{$\mathrm{P} 1$} & \multicolumn{2}{c}{$\mathrm{P} 2$} & \multicolumn{2}{c}{$\mathrm{P} 3$} \\
\cline { 2 - 7 } & \multicolumn{1}{c}{$12-\mathrm{h}$} & \multicolumn{1}{c}{$24-\mathrm{h}$} & \multicolumn{1}{c}{ 12-h } & \multicolumn{1}{c}{$24-\mathrm{h}$} & \multicolumn{1}{c}{ 12-h } & \multicolumn{1}{c}{ 24-h } \\
\hline Foaming (\%) & 607.50 & 582.50 & 491.25 & 496.25 & 507.50 & 562.50 \\
Foam stability (\%) & 82.61 & 83.35 & 77.40 & 79.62 & 84.48 & 77.57 \\
\hline
\end{tabular}

Table 3. The effect of $K$. lactis fermentation to the chemical properties of egg white powder

\begin{tabular}{lrrrrrr}
\hline \multirow{2}{*}{ Chemical properties } & \multicolumn{2}{c}{ P1 } & \multicolumn{2}{c}{ P2 } & \multicolumn{2}{c}{ P3 } \\
\cline { 2 - 7 } & $12-\mathrm{h}$ & \multicolumn{1}{c}{ 24-h } & \multicolumn{1}{c}{ 12-h } & \multicolumn{1}{c}{ 24-h } & \multicolumn{1}{c}{ 12-h } & \multicolumn{1}{c}{ 24-h } \\
\hline Water (\%) & 12.91 & 12.70 & 12.14 & 12.88 & 11.70 & 13.75 \\
Ash (\%) & 21.03 & 25.61 & 21.64 & 27.29 & 26.97 & 26.13 \\
Protein (\%) & 81.72 & 80.42 & 81.60 & 81.97 & 83.16 & 83.86 \\
Carbohydrate (\%) & 0.17 & 0.22 & 0.17 & 0.16 & 0.20 & 0.15 \\
\hline
\end{tabular}


In certain condition, potassium could be replaced by magnesium or natrium but resulted in lagging fermentation process. In this research, the higher $K$. lactis starter concentration showed slower fermentation, thus indicate that the potassium was not utilized optimally. The high ash content would affect the nutritional value of the food product, as well as causing darkish colour. Fermentation would increase the ash content as the process would utilize carbohydrates, such as glucose, into organic acids and other compounds, such as minerals. In this research, it can be seen that $K$. lactis fermentation would increase the ash and protein content in the egg white powder.

\section{The effect of $K$. lactis starter concentration and fermentation time on protein content}

The complete essential amino acid in the egg white caused the product to have high nutritional value (Winarno and Koswara, 2004). The higher protein content in food products would result in better functional properties as well. According to Muchtadi (2010), higher yeast concentration in fermentation would result in higher macromolecules breakdown into simpler molecules. This research showed that egg white powder with $0.6 \% \quad K$. lactis fermentation showed higher protein content, which was $83.51 \%$. The result is higher than research by Nusa et al. (2017) who showed that the highest protein content in tempeh yeast fermented egg white had 55.59\% protein content.

The increased protein content in this research is allegedly due to the increased microbial protein (from yeast) during fermentation. The condition is in accordance with Smith and Hull (2014) who showed that the protein content would be increased along with single-cell protein conformation. Yosia and Margareta (2016) also showed that glucose metabolism into pyruvic acid would produce intermediary compounds which would be utilized for amination and/or transamination in amino acids production. In addition, one of the produced amino acids was serin, formed from 3-phosphoglycerat synthesis, which would be utilized to produce glycine and cysteine through glycolysis.

\section{The effect of $K$. lactis starter concentration and fermentation time on carbohydrate content}

Glucose is the major carbohydrate in egg, which make up for around $98 \%$ of carbohydrate in the egg white. According to Raikos et al. (2007), the reduced sugar could be produced by the reactive hydroxyl compound in 1 atom. Nahariah et al. (2010) showed that one of the methods to reduce the reduced sugar content in egg white powder is by releasing hydrogen bond through fermentation. This research showed that the average carbohydrate content was decreased along with the higher $K$. lactis starter concentration. The addition of $0.6 \% \mathrm{~K}$. lactis would result in higher carbohydrate reduction. According to Bell and Weaver (2002), the carbohydrate content in egg white is around $0.40-0.90 \%$. The carbohydrate content would also affect the colour of egg white powder due to the Maillard reaction. In this research, the Maillard reaction was not found during drying. The inhibition of Maillard reaction was due to the sugar reduction through $K$. lactis fermentation.

The result is in accordance with Yurliasni (2009) who mentioned that $K$. lactis could utilize lactose, glucose, and galactose as main carbon source for cell growth. Moreover, the utilization of carbohydrate in egg white is allegedly through glycolysis and citric acid cycle, which produced energy, $\mathrm{CO}_{2}$, and $\mathrm{H}_{2} \mathrm{O}$, as well as other molecules biosynthesis for cell metabolism. The low carbohydrate content in this research was due to dominant lactose fermentation by $K$. lactis. In addition, the yeast would also secrete $\beta$-galactosidase, a lactose degrading enzyme. The standard of maximum carbohydrate content in egg white powder according to National Standardization Agency of Indonesia (SNI $01-4323-1996)$ is $0.5 \%$, thus the all of the 
egg white powders in this research are according to the standard. The results showed that $0.2 \% \mathrm{~K}$. lactis fermentation for 24-h would produce the highest carbohydrate content, while the lowest was obtained in $0.6 \% \mathrm{~K}$. lactis fermentation for 24-h.

\section{CONCLUSIONS}

The research concludes that the starter concentration of $K$. lactis and fermentation time affect the physicochemical and functional properties of egg white powder, with the best treatment, was found in $0.6 \%$ Kluyveromyces lactis fermentation for $24 \mathrm{~h}$.

\section{ACKNOWLEDGMENTS}

We would like to thank the research team and DRPMI (Direktorat Riset dan Pengabdian Pada Masyarakat dan Inovasi) UNPAD for the research funding.

\section{REFERENCES}

AOAC. (2006). Official Methods of Analysis. In Assosiation of Official Analitical Chemist. Washington, D.C.

Ariyanti, D., \& Hadiyanto, H. (2013). Ethanol production from whey by kluyveromyces marxianus in batch fermentation system: kinetics parameters estimation. Bulletin of Chemical Reaction Engineering \& Catalysis, 7(3), 179-184. https://doi. org/10.9767/bcrec.7.3.4044.179-184

Bambang, N., \& Nurhasanah, S. (2010). Sifat Fisik Bahan Pangan. UNPAD.

Barnett, J., \& Pankhrust, R. (2000). A New Key to the Yeast. New York: American Elsevier Publishing Company.

Bell, D., \& Weaver, W. (2002). Comercial Chicken Meat and Egg Production (5th ed.). New York: Springer Science and Business Media.
Buckle, K., Edwards, R., Fleet, G., \& Wootton, M. (2007). Ilmu Pangan (H. Purnomo \& Adiono, Eds.). Jakarta: Universitas Indonesia Press.

Lechevalier, V., Jeantet, R., Arhaliass, A., Legrand, J., \& Nau, F. (2007). Egg white drying: Influence of industrial processing steps on protein structure and functionalities. Journal of Food Engineering, 83(3), 404-413. https://doi. org/10.1016/J.JFOODENG.2007.03.033

Lestari, P, I. (2009). Kajian Supply Chain Management: Analisis Relationship Marketing antara Peternakan Pamulihan Farm dengan Pemasok dan Pelanggannya. Bogor: Institut Pertanian Bogor Press.

Luo, Z.-G., \& Shi, Y.-C. (2012). Preparation of acetylated waxy, normal, and highamylose maize starches with intermediate degrees of substitution in aqueous solution and their properties. Journal of Agricultural and Food Chemistry, 60(37), 9468-9475. https://doi.org/ 10.1021/jf301178c

Muchtadi, T., \& Ayustaningwarno, F. (2010). Teknologi Proses Pengolahan Pangan. Bogor: Institut Pertanian Bogor Press.

Nahariah, E., Abustam, \& Malaka, R. (2010). Karakteristik Fisikokimia Tepung Putih Telur Hasil Fermentasi Saccharomyces cereviceae Dan Penambahan Sukrosa Pada Putih Telur Segar. Universitas Hasanuddin.

Nahariah, N., Legowo, A., Abustam, E., Hintono, A., \& Hikmah, H. (2018). Functional characteristics of fermented egg white powder after pan-drying at different temperatures and times. International Journal of Poultry Science, 17(3), 134-139. https://doi.org/10.3923/ijps.2018.134.139 
Nusa, M. I., Suarti, B., \& Marbun, R. A. (2017). Addition of tempe and old fermentation to the quality of albumin flour egg. AGRIUM: Jurnal Ilmu Pertanian, 20(3), 211-221. https://doi. org/10.30596/AGRIUM.V20I3.1051

Puspitasari, R. (2006). Sifat Fisik dan Fungsional Tepung Putih Telur Ayam Ras dengan Waktu Desugarisasi Berbeda. Bogor: Institut Pertanian Bogor.

Pujimulyani, D., Andiwarsana, S., \& Suprapti, S. (2016). Pengaruh waktu fermentasi terhadap sifat fungsional dan warna tepung albumin telur itik. AgriTECH, 21(3), 108-112. https:// doi.org/10.22146/agritech.13594

Raikos, V., Campbell, L., \& Euston, S. R. (2007). Rheology and texture of hen's egg protein heat-set gels as affected by $\mathrm{pH}$ and the addition of sugar and/or salt. Food Hydrocolloids, 21(2), 237244. https://doi.org/10.1016/J.FOOD HYD.2006.03.015

Roostita, L. B., Fleet, G., Yurliasni, S., \& Wendry. (2014). Potensi Yeast (Khamir) dalam Bahan Pangan. Bandung: UNPAD Press.

Rosa, J. C. C., Colombo, L. T., Alvim, M. C. T., Avonce, N., Van Dijck, P., \& Passos, F. M. L. (2013). Metabolic engineering of Kluyveromyces lactis for L-ascorbic acid (vitamin C) biosynthesis. Microbial Cell Factories, 12(1), 59. https://doi.org/ $10.1186 / 1475-2859-12-59$

Roxana, N. R., Usturoi, M., \& Aida, A. (2015). Quality of powder egg stored in different conditions. Lucrari Stiintifice-Seria Zootehnie, 63, 122-127.
Siregar, R. F., Hintono, A., \& Mulyani, S. (2012). Perubahan sifat fungsional telur ayam ras pasca pasteurisasi. Animal Agriculture Journal, 1(1), 521-528.

Smith, J. S., \& Hull, Y. (2013). Food Processing Principles and Applications (J. Wiley \& Sons, Eds.). Ltd. Published.

Triawati, N. W., Thohari, I., \& Rosyidi, D. (2013). Evaluasi Sifat Putih Telur Ayam Pasteurisasi Ditinjau dari Daya Buih, Stabilitas Buih, Daya Koagulasi dan Daya Kembang Sponge Cake. Malang: Universitas Brawijaya.

Winarno, F. G., \& Koswara, S. (2004). Telur: Komposisi, Penanganan dan Pengolahannya. Bogor: Mbrio Press.

Winarti, E., \& Trianini. (2005). Peluang Telur Invertil Pada Usaha Penetasan Telur Itik Sebagai Telur Konsumsi. Seminar Nasional Teknologi Peternakan dan Venteriner.

Yosia, A. S., Sri, H., \& Margareta, N. C. (2016). Optimasi Kandungan Gizi Tepung Ubi Jalar (Ipomoea Batatas L.) Terfermentasi Ditinjau Dari Dosis Penambahan Inokulum Angkak Serta Aplikasinya Dalam Pembuatan Mie Basah. Universitas Kristen Satya Wacana.

Yurliasni. (2009). Pertumbuhan dan Aktivitas Khamir. Bandung: UNPAD Press.

Yuwanta, T. (2010). Telur dan Kualitas Telur. Yogyakarta: Gadjah Mada Press. 